\title{
PROTEOLYSIS OF PRATO TYPE CHEESE PRODUCED USING ULTRAFILTRATION
}

\author{
Leila Maria Spadoti*; José Raimundo Ferreira Dornellas; Salvador Massaguer Roig \\ UNICAMP/FEA - Depto. de Tecnologia de Alimentos, C.P. 6121 - 13083-970 - Campinas, SP - Brasil. \\ *Corresponding author <lspadoti@ital.sp.gov.br>
}

\begin{abstract}
The application of milk ultrafiltration technology for cheese manufacture presents several advantages. However, it also influences proteolysis and, consequently, cheese ripening. The effects of five different processing methods for Prato cheese were evaluated with respect to the time evolution of the extent and depth of proteolysis indexes (EPI and DPI). The following treatments (T) for cheese production were studied: T1 - without ultrafiltration (standard); T2, T3, T4 and T5 - using milk concentrated by ultrafiltration (UFCM) and respectively: T2 - without pre-fermentation of the UFCM; T3 - pre-fermentation of $10 \%$ of the UFCM; T4 - pre-fermentation of $20 \%$ of the UFCM, and T5 - pre-fermentation of $20 \%$ of the UFCM plus indirect heating. Treatments affected the EPI and DPI of the cheeses (T1 lower values for EPI and DPI and T4 higher values for EPI and DPI). The time influenced the extent and depth of proteolysis indexes.

Key words: milk, membrane technology, ripening
\end{abstract}

\section{PROTEÓLISE DE QUEIJO TIPO PRATO PRODUZIDO UTILIZANDO ULTRAFILTRAÇÃO}

\begin{abstract}
RESUMO: A aplicação da tecnologia de ultrafiltração do leite para fabricação de queijos apresenta inúmeras vantagens, porém, ela também influi na proteólise, e conseqüentemente na maturação dos queijos. Foram avaliados os efeitos de cinco diferentes métodos de processamento de queijo Prato sobre a evolução dos índices de extensão e profundidade da proteólise (EPI e DPI). Os seguintes tratamentos (T) para produção de queijo foram estudados: T1 - sem ultrafiltração (padrão); T2, T3, T4 e T5 - usando leite concentrado por ultrafiltração (UFCM) e respectivamente: T2 - sem pré-fermentação do UFCM, T3 - pré-fermentação de $10 \%$ do UFCM; T4 - pré-fermentação de $20 \%$ do UFCM e T5 - pré-fermentação de $20 \%$ do UFCM com aquecimento indireto. O tratamento afetou o EPI e o DPI dos queijos (T1 menores valores para EPI e DPI e T4 maiores valores para EPI e DPI). O tempo influenciou os índices de extensão e profundidade da proteólise. Palavras-chave: leite, tecnologia de membrana, maturação
\end{abstract}

\section{INTRODUCTION}

Prato cheese, typical from Brazil, is produced by enzymatic coagulation and partial cooking stage, carried out by the addition of hot water or by heating of the vat. It must be ripened for 25 days minimum (Souza, 1960; Nova legislação..., 1998).

For most cheeses, proteolysis is the main indicator of ripening, usually expressed by the extent and depth of proteolysis indexes (EPI and DPI). EPI reflects the percent of decomposed protein molecules, mostly to large peptides, and DPI the percent to which these large peptides are degraded into smaller molecules (Baldini, 1998; Farkye \& Fox, 1990; Sousa et al., 2001; WolfschoonPombo, 1983).

Milk concentrated by ultrafiltration can alter the cheese ripening process in various ways, as a result of the residual whey proteins content and their state; coagulation $\mathrm{pHs}$; the final curd $\mathrm{pH}$ after pressing and salting; the ratio of coagulant/raw milk or coagulant/casein be- ing transformed on cheese (Green et al., 1981; Hickey et al., 1983; Koning et al., 1981; Lelievre \& Lawrence, 1988; Renner \& Abd El-Salam, 1991). Other factors such as moisture, temperature, salt content etc, which normally influences cheese ripening, also will influence quality of Prato cheese.

Ribeiro (1996) produced Prato cheese from ultra filtration-concentrated milk (UFCM) with various concentration factors (CF) $(1.5: 1 ; 2.5: 1 ; 3.5: 1$ and 5.0:1) and obtained cheeses with typical organoleptic and textural characteristics, and better yield than traditional process. However it was only possible to obtain adequate texture with a $\mathrm{CF}=5: 1$ and by pre-fermenting $10 \%$ of the retentate with a lactic culture.

The objective of this research was to study the effect of the use of UFCM to a CF of 4:1, the pre-fermentation (10 and 20\%) and the type of the curd cooking, on the EPI and DPI in the manufacture of Prato cheese and compare the results to those of a standard cheese. 


\section{MATERIAL AND METHODS}

\section{Milk ultrafiltration}

Whole raw milk $(250 \mathrm{~kg})$ from Campinas Region (State of São Paulo - Brazil), was heat treated at $68^{\circ} \mathrm{C}$ for $2 \mathrm{~min}$. Part of this milk (50 kg) was cooled to $35^{\circ} \mathrm{C}$ and used to produce a batch of standard Prato cheese (T1). The remaining $200 \mathrm{~kg}$ were cooled to $55^{\circ} \mathrm{C}$ and submitted to concentration by ultrafiltration on the same day the milk was delivered to the pilot plant.

The milk was concentrated with Carbosep mineral membranes (Tech-sep, Soc. An. - Groupe Rhône Poulenc, Saint-Maurice de Beynost, France) with a molecular mass cut-off of 20,000 Daltons, inlet and outlet pressures of $2.45 \times 10^{5}$ and $1.47 \times 10^{5} \mathrm{~Pa}$ respectively, up to CF $4: 1$. The ultrafiltration concentration process last approximately 10 hours. The ultrafiltered milk was then pasteurized at $62^{\circ} \mathrm{C}$ for $30 \mathrm{~min}$, cooled to $7^{\circ} \mathrm{C}$ and divided into four equal parts to be used for manufacture of cheeses T2, T3, T4 and T5 on the next day.

\section{Cheese manufacture}

Three processing procedures were carried out on different dates. In each processing, five batches of Prato cheese were manufactured.

In for the UFCM, manufactured cheese (T2, T3, T4 and T5), after cooling the UFCM, a certain portion was removed from each batch $(0 \%$ from $\mathrm{T} 2 ; 10 \%$ from $\mathrm{T} 3$ and $20 \%$ from $\mathrm{T} 4$ and $\mathrm{T} 5$ ) and submitted to pre-fermentation with mesophilic starter (G3 MIX 6VISBYVAC $^{\circledR}$-B50 - composed of multiple mixed strains of Lactococcus lactis ssp. lactis and Lactococcus lactis ssp. cremoris) at $32^{\circ} \mathrm{C}$. The rest of the UFCM was stored at $5 \pm 1{ }^{\circ} \mathrm{C}$ until the next day.

After the separated portions had reached $\mathrm{pH}$ 5.0, they were mixed with their respective UFCM batches and heated to $35^{\circ} \mathrm{C}$ to start the processing of the cheese. Both the standard cheese and those prepared from UFCM were manufactured according to regular processing of Prato cheese.

For the standard cheese, calcium chloride $(0.4 \mathrm{~mL}$ $\mathrm{kg}^{-1}$ milk of a $50 \% \mathrm{w} / \mathrm{w}$ solution) was added to the milk already heated to $35^{\circ} \mathrm{C}$, followed by the addition of freeze dried, ready to use starter (one tenth of the quantity recommended by the manufacturer), annatto dye (Bixa orellana) (Chr. Hansen Ind. e Com. Ltda, Valinhos, SP, Brazil) and rennet (calf rennet - 90\% chymosin) (BV Ind. e Com. Ltda, Valinhos, SP, Brazil) sufficient to coagulate the milk at $35^{\circ} \mathrm{C}$.

For cheeses manufactured from UFCM, starter, dye and coagulating agent were used in quantities equivalent to what would be used if UFCM were converted into milk, but without the addition of calcium chloride. After coagulation (40 min), the curd was cut into $0.4 \mathrm{~cm} \times 0.5$ $\mathrm{cm}$ cubes, and allowed to rest for $5 \mathrm{~min}$. The curds were then submitted to slow continuous mixing for $20 \mathrm{~min}\left(1^{\text {st }}\right.$ mixing), followed by removal of part of the whey and further heating of the curd $\left(2^{\text {nd }}\right.$ mixing) to $41^{\circ} \mathrm{C}$ with the addition of hot water, to obtain the correct consistency for Prato cheese.

For cheeses obtained from UFCM, no $1^{\text {st }}$ mixing or whey removal was carried out, the curd being heated soon after the resting period, resulting in 30-min reduction of the processing time. For the cheeses T2, T3 and T4, the curd was heated directly by the addition of hot water. For T5, the curd was heated indirectly. After heating, curds were pre-pressed for $20 \mathrm{~min}$ in a draining press with twice the weight of the curd, and then placed in plastic molds and pressed for $6 \mathrm{~h}$ in a vertical press, with stainless steel weights. The cheeses were turned after 20 min during pressing and then every hour until removed from the press. The weights were gradually increased from 10 to 20 times the weight of the curd. After pressing was completed cheeses were stored at $7 \pm 1^{\circ} \mathrm{C}$ and the next day placed in a $20 \% \mathrm{NaCl}$ solution for a period of $8 \mathrm{~h}$ at $4 \pm 1^{\circ} \mathrm{C}$. Finally, cheeses were dried at $7 \pm 1^{\circ} \mathrm{C}$, weighed, sealed under vacuum in plastic bags and stored at $7 \pm 1^{\circ} \mathrm{C}$ for $45 \mathrm{~d}$.

\section{Analysis}

Total nitrogen (TN) was determined by Kjeldahl method AOAC (1995). Soluble nitrogen at $\mathrm{pH} 4.6$ and soluble nitrogen in $12 \%$ trichloroacetic acid (TCA) were determined according to Barbano et al. (1991) and AOAC (1995), respectively. Total solid (TS) content was determined using AOAC method 925.23 (AOAC, 1995) and Moisture (M) content using the equation: $\mathrm{M}=100-\mathrm{TS}$. The values for $\mathrm{pH}$ were determined by the potentiometric method and those for titratable acidity (TA) and salt content using the AOAC method 920.124 (AOAC, 1995) and the Volhard method (Richardson, 1985), respectively. The salt content in the moisture $(\mathrm{S} / \mathrm{M})$ was calculated from equation: $\mathrm{S} / \mathrm{M}=($ salt $\times 1000) /$ moisture. All the above determinations were carried out in triplicate on the cheeses after $10 \mathrm{~d}$. The cheeses were monitored for $\mathrm{pH}$, TA, and proteolysis during 45 days. The analyses were carried out after 10, 25 and 45 days of refrigerated storage (D10, D25 and D45). Proteolysis was evaluated by the extent and depth of proteolysis indexes using the following equations:

$\mathrm{EPI}=\frac{(\% \text { soluble nitrogen at } \mathrm{pH} 4.6) \times 100}{\% \text { total nitrogen }}$

$\mathrm{DPI}=\underline{(\% \text { solubre nitrogen in } 12 \% \mathrm{TCA}) \times 100}$

\section{Experimental design and statistical analysis}

The statistical design adopted for this experiment was a split-plot block design, treatments being the plots 
and time the sub-plots. The batches of milk constituted the blocks. Three batches were carried out, one for each complete replicate. Data were submitted to analysis of variance, using the procedure of multiple comparisons between pairs of means (Tukey's method) on the tenth day after manufacture of the cheeses. The data for the analyses of $\mathrm{pH}$, titratable acidity and proteolysis indexes were evaluated in the same way as those for composition, on the tenth, twenty-fifth and forty-fifth days of storage. All the calculations were carried out with the aid of the SAS statistical program (SAS System for Windows, Release 8.02 - SAS Institute Inc, 2001).

\section{RESULTS AND DISCUSSION}

\section{Cheese composition}

The use of ultrafiltration tended to increase protein concentration of the cheese (whey proteins and caseins), although treatments did not differ among themselves (Table 1). One of the advantages of the use of ultrafiltration is the inclusion of whey proteins in the cheese, as a result of the decrease or elimination of the whey removal stage (Hydamaka et al., 2001). Also the values of salt in moisture showed no difference for the treatments (Table 1). According to Fox et al. (2000), they were in the normal range for cheeses similar to Prato cheese which avoid flavor defects due to improper salting.

\section{Evolution of Titratable Acidity and pH values}

There was no interaction for titratable acidity $\mathrm{x}$ time $(P=0.24)$, and the values for TA of the cheeses showed variations with time $(P<0.01)$ and with the type of treatment adopted $(P=0.02)$. Between the dates D10 and D25, an increase of the treatments TA was observed, although there were no differences between days D25 and D45. Tukey's test with respect to the treatments showed that $\mathrm{T} 1$ did not differ from treatments T2, T3 and T5, but differed from T4; T4 also did not differ from treatments T2, T3 and T5.

There was no interaction of $\mathrm{pH}$ data $\mathrm{x}$ time $(P=$ $0.75)$ and the $\mathrm{pH}$ values of the different cheeses were not influenced by the factor time $(P=0.45)$. However they were influenced $(P=0.03)$ by the type of treatment. T1 did not differ from treatments T2, T3 and T5, but differed from T4; T4 also did not differ from treatments T2, T3 and T5 $(P>0.05)$.

The behavior of the $\mathrm{pH}$ and titratable acidity of the cheeses during storage (Table 2) showed similar values to those observed by Cichoscki et al. (2002). For a period of 60 days, Cichoscki et al. (2002) evaluated the evolution of the $\mathrm{pH}$ and TA of 18 batches of Prato cheese, manufactured in eight municipalities in the region of Alto Uruguai (State of Rio Grande do Sul, Brazil), and showed that the $\mathrm{pH}$ of the cheeses did not vary during storage, remaining in the range from 5.3 to 5.5 (as the standard cheese in this experiment). They also observed that the

Table 1 - Average composition $(\mathrm{n}=3)$ of the ten day-old cheeses obtained: without ultrafiltration $(\mathrm{T} 1)$ and with ultrafiltration (CF 4:1): without pre-fermentation (T2), with $10 \%$ pre-fermentation (T3), with $20 \%$ pre-fermentation (T4) and with $20 \%$ pre-fermentation and indirect heating (T5).

\begin{tabular}{lcrrrr}
\hline Variable & $\mathrm{T} 1$ & $\mathrm{~T} 2$ & $\mathrm{~T}$ & $\mathrm{~T} 4$ & $\mathrm{~T} 5$ \\
\hline$\%$ & & & & & \\
Total solids & $51.77^{\mathrm{ab}}$ & $48.77^{\mathrm{b}}$ & $52.89^{\mathrm{ab}}$ & $54.95^{\mathrm{a}}$ & $55.47^{\mathrm{a}}$ \\
Total protein & $18.42^{\mathrm{a}}$ & $21.38^{\mathrm{a}}$ & $22.51^{\mathrm{a}}$ & $21.86^{\mathrm{a}}$ & $22.24^{\mathrm{a}}$ \\
Salt & $1.60^{\mathrm{a}}$ & $1.67^{\mathrm{a}}$ & $1.48^{\mathrm{a}}$ & $1.36^{\mathrm{a}}$ & $1.44^{\mathrm{a}}$ \\
Moisture & $48.23^{\mathrm{ab}}$ & $51.23^{\mathrm{a}}$ & $47.11^{\mathrm{ab}}$ & $45.05^{\mathrm{b}}$ & $44.53^{\mathrm{b}}$ \\
Salt/Moisture & $3.31^{\mathrm{a}}$ & $3.26^{\mathrm{a}}$ & $3.14^{\mathrm{a}}$ & $3.09^{\mathrm{a}}$ & $3.23^{\mathrm{a}}$ \\
\hline
\end{tabular}

*Means with the same letter, in the same line, do not differ $(P>0.05)$ by Tuckey's multiple comparison method.

Table 2 - Evolution of the titratable acidity and of the $\mathrm{pH}$ during storage of the cheeses obtained: without ultrafiltration (T1) and with ultrafiltration (CF 4:1): without pre-fermentation (T2), with $10 \%$ pre-fermentation (T3), with $20 \%$ prefermentation (T4) and with $20 \%$ pre-fermentation and indirect heating (the only one) (T5).

\begin{tabular}{lcccccc}
\hline Variable & Time & T1 & T2 & T3 & T4 & T5 \\
\hline & days & & & & & \\
Titratable acidity (\% lactic acid) & 10 & 0.64 & 0.71 & 0.86 & 1.28 & 1.12 \\
Titratable acidity (\% lactic acid) & 25 & 0.77 & 0.91 & 0.90 & 1.40 & 1.21 \\
Titratable acidity (\% lactic acid) & 45 & 0.93 & 0.95 & 0.87 & 1.35 & 1.21 \\
$\mathrm{pH}$ & 10 & 5.37 & 5.37 & 5.28 & 5.00 & 5.09 \\
$\mathrm{pH}$ & 25 & 5.47 & 5.27 & 5.29 & 4.99 & 5.12 \\
$\mathrm{pH}$ & 45 & 5.32 & 5.15 & 5.27 & 5.03 & 5.09 \\
\hline
\end{tabular}

Sci. Agric. (Piracicaba, Braz.), v.62, n.3, p.235-239, May/June 2005 
TA values increased during the first month of storage, but that the TA values did not vary between 30 and 45 days of storage.

\section{Evolution of proteolysis}

There was no treatment $\mathrm{X}$ time interaction for EPI and DPI ( $P=0.88$ and $P=0.33$, respectively), and the values for EPI and DPI of the cheeses showed variation with storage time $(P<0.01)$ and with the type of treatment $(P<0.01$ and $P=0.04$, respectively). The two indexes increased during storage, the values for D10<D25<D45 in both cases (Figures 1 and 2).

\section{Extent of proteolysis}

The EPI values of cheeses T3, T4 and T5 did not differ, even though in absolute terms cheeses T4 and T5 showed the highest indexes. In addition, cheese T3 did not differ from cheese T2. The standard cheese showed the lowest EPI, differing from the other treatments.

Wolfschoon-Pombo (1983) and Baldini (1998) found EPI values for Prato cheese in the range of 11.9 to $14 \%$ after about one month of storage. The cheese T1 presented an EPI value near to $14 \%$ after 25 days of storage, but the cheeses from the other treatments presented higher values than the standard (Figure 1). These results contradicts data from (Lelievre \& Lawrence, (1988); and Renner \& Abd El-Salam, (1991) who reported that cheeses manufactured from UFCM tended to present less proteolysis than cheeses made from nonultrafiltered milk.

In the break up of casein into large peptides, chymosin is the main enzyme responsible for cheese proteolysis (Fox et al., 2000). Therefore, EPI depends on the quimosin concentration used, the amount of quimosin retained on the curd after the whey removal, and on its activity as function of the final curd $\mathrm{pH}$, being that both, the percent retention of this enzyme in the cheeese and its activity during ripening, are $\mathrm{pH}$ dependente and fa-

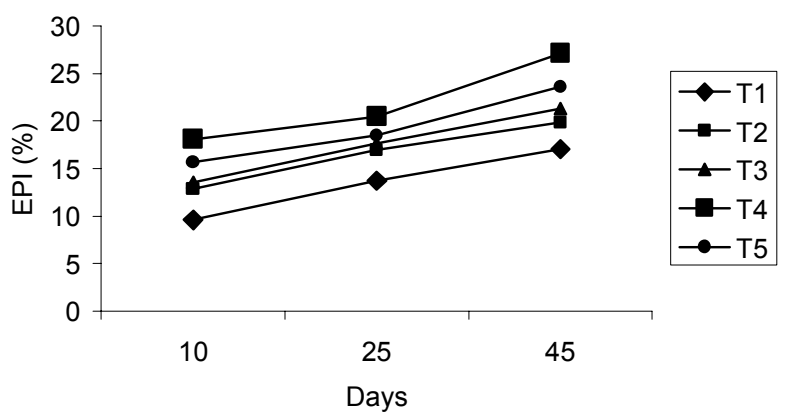

Figure 1 - Evolution of the extent of proteolysis index (EPI) during storage of the cheeses obtained: without ultrafiltration (T1) and with ultrafiltration (CF 4:1): without prefermentation (T2), with $10 \%$ pre-fermentation (T3), with $20 \%$ pre-fermentation (T4) and with $20 \%$ prefermentation and indirect heating (the only one) (T5). vored by low $\mathrm{pH}$ values (Walstra et al., 1999). The quimosin action, besides $\mathrm{pH}$, is also influenced by the presence of whey proteins, which tend to dificult quimosin access to caseins (Lelievre \& Lawrence, 1988; Walstra et al., 1999).

Therefore, the behavior of the cheeses probably resulted from the $\mathrm{pH}$ values presented by the cheeses from the different treatments, during storage (Table 2). Thus, cheeses showing not only lower $\mathrm{pH}$ values (T4 and T5), but also larger whey protein content, presented greater EPI values; highest $\mathrm{pH}$ value (T1), were associated to lowest EPI value.

\section{Depth of proteolysis}

The DPI values of cheeses T2, T3, T4 and T5 did not differ within the group, the T4 cheese showing the highest index followed by the T5 cheese and then by cheeses T3 and T2. However, cheese T3 at 25 and 45 days of ripening presented a even lower DPI than cheese T2 made without pre-fermentation, and cheese T2 made without pre-fermentation did not differ from cheeses T3, T4 and T5. The standard cheese (T1) presented the lowest DPI, although not different from cheeses T2, T3 and T5.

The depth of proteolysis in a cheese is mainly determined by the action of enzymes from the lactic starter (Walstra et al., 1999). Thus cheeses T4 and T5 probably presented greater DPI values due to a greater development of the lactic starter.

Analyses carried out by Baldini (1998) in Prato cheese manufactured with non-ultrafiltered milk registered the following DPI values: $4.18 \%$ for cheeses with one week of storage, 6.57 after four weeks of storage, and 7.26 after six weeks. These values are greater than those obtained for the standard cheese in this experiment, although close to those determined for the cheeses T4 and T5 (Figure 2).

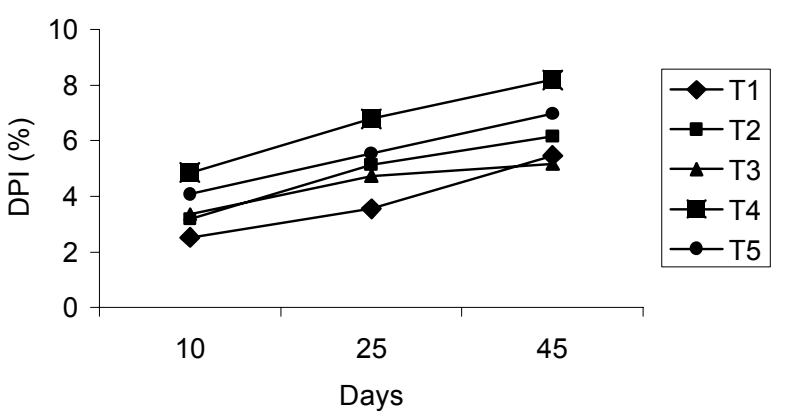

Figure 2 - Evolution of the depth of proteolysis index (DPI) during storage of the cheeses obtained: without ultrafiltration (T1) and with ultrafiltration ( $\mathrm{CF} 4: 1$ ): without prefermentation (T2), with $10 \%$ pre-fermentation (T3), with $20 \%$ pre-fermentation (T4) and with $20 \%$ prefermentation and indirect heating (the only one) (T5). 


\section{CONCLUSIONS}

The possibility of obtaining Prato cheese from milk concentrated by ultrafiltration at a concentration factor of 4:1, was confirmed with a ripening behavior, evaluated by the extent and depth of proteolysis indexes, more intense than a standart Prato cheese made by the traditional process, and similar to values reported on the literature for Prato cheese made from milk by the traditional process. The modifications alow the acceleration or retardation of proteolysis of Prato cheese manufactured from milk concentrated by ultrafiltration, which is important for the industry either for when it is of interest to increase the commercialization window, during the season of larger milk production, as well for when it is of interest to reduce the time between production and commercialization.

\section{ACKNOWLEDGEMENTS}

To CNPq (doctorate scholarships authors 1 and 2) and to FAPESP (Research grant 00/14079-8).

\section{REFERENCES}

ASSOCIATION OF ANALYTICAL CHEMISTS-AOAC. Official methods of analysis of AOAC international. Washington: AOAC, 1995. 109p.

BARBANO, D.M.; LYNCH, J.; FLEMING, J.R. Direct and indirect determination of true protein content of milk by Kjeldahl analysis: collaborative study. Journal of the AOAC, v.74, p.281-288, 1991.

BALDINI, V.L.S. Proteólise em queijo tipo Prato durante a maturação. São Paulo: USP/FCF, 1998. 208p. (Tese - Doutorado).

CICHOSCKI, A.J.; VALDUGA, E.; VALDUGA, A.T.; TORNADIJO, M.E.; FRESNO, J.M. Characterization of Prato cheese, a Brazilian semi-hard cow variety: evolution of physico-chemical parameters and mineral composition during ripening. Food Control, v.13, p.329-336, 2002.

FARKYE, N.Y.; FOX, P.F. Objective indices of cheese ripening. Trends in Food Science \& Technology, v.1, p.37-40, 1990.

FOX, P.F.; GUINEE, T.P.; COGAN, T.M.; McSWEENEY, P.L.H. Fundamentals of cheese science. Gaithersburg: Aspen Publishers, 2000 $587 \mathrm{p}$.
GREEN, M.L.; GLOVER, F.A.; SCURLOCK, E.M.W.; MARSHALL, R.J.; HATFIELD, D.S. Effect of use of milk concentrated by ultrafiltration on the manufacture and ripening of Cheddar cheese. Journal of Dairy Research, v.48, p.333-341, 1981.

HICKEY, M.W.; VAN LEEUWEN, H.; HILLIER, A.J.; JAGO, G.R. Amino acid accumulation in cheddar cheese manufactured from normal and ultrafiltered milk. Australian Journal of Dairy Technology, v.38, p.110$113,1983$.

HYDAMAKA, A.W.; WILBEY, R.A.; LEWIS, M.J.; KUO, A.W. Manufacture of heat and acid coagulated Cheese from ultrafiltered milk retentates. Food Research International, v.34, p.197-205, 2001.

KONING, P.J.; BOER, R.; BOTH, P.; NOOY, P.F.C. Comparison of proteolysis in a low fat semi-hard type of cheese manufactured by standard and by ultrafiltration techniques. Netherlands Milk and Dairy Journal, v.35, p.35-46, 1981.

LELIEVRE, J.; LAWRENCE, R.C. Manufacture of cheese from milk concentrated by ultrafiltration. Journal of Dairy Research, v.55, p.465$478,1988$.

NOVA LEGISLAÇÃO de produtos lácteos e de alimentos para fins especiais, diet, light e enriquecidos. São Paulo: Fonte Comunicações e Editora, 1998. 212p.

RENNER, E.; ABD EL-SALAM, M.H. Application of ultrafiltration in the dairy industry. London: Elsevier Applied Science, 1991. 371p.

RIBEIRO, E.P. Aplicação da ultrafiltração de leite no processo de fabricação de queijo tipo prato. Campinas: UNICAMP/FEA, 1996. 144p. (Tese Doutorado).

RICHARDSON, G.H. Standard methods for examination of dairy products. Washington: APHA, 1985. p.339-344.

SAS INSTITUTE INC. Statistical analysis systems. Version 8.02, Cary, 2001.

SOUZA, E.A. Tecnologia da fabricação de queijos. Juiz de Fora: Editora Lar Católico, 1960. 116p.

SOUSA, M.J.; ARDO, Y.; McSWEENEY, P.L.H. Advances in the study of proteolysis during cheese ripening. International Dairy Journal, v.11, p.327-345, 2001

WALSTRA, P.; GEURTS, T.J.; NOOMEN, A.; JELLEMA, A.; VAN BOEKEL, M.A.J.S. Dairy technology. New York: Marcel Dekker, 1999. $726 \mathrm{p}$.

WOLFSCHOON-POMBO, A.F. Índices de proteólise em alguns queijos brasileiros. Boletim do Leite, v.55, p.1-8, 1983.

Received July 23, 2004

Accepted March 02, 2005 